\title{
Interleukin-32a promotes the proliferation of multiple myeloma cells by inducing production of IL- 6 in bone marrow stromal cells
}

\author{
Xuanru Lin ${ }^{1, *}$, Li Yang ${ }^{1, *}$, Gang Wang ${ }^{2}$, Fuming $Z^{i}{ }^{3}$, Haimeng Yan ${ }^{1}$, Xing Guo ${ }^{1}$, Jing \\ Chen ${ }^{1}$, Qingxiao Chen ${ }^{1}$, Xi Huang ${ }^{1}$, Yi Li ${ }^{1}$, Enfan Zhang ${ }^{1}$, Wenjun Wu ${ }^{1}$, Yang Yang ${ }^{1}$, \\ Donghua $\mathrm{He}^{1}$, Jingsong $\mathrm{He}^{1}$ and Zhen $\mathrm{Cai}^{1}$

\begin{abstract}
${ }^{1}$ Bone Marrow Transplantation Center, The First Affiliated Hospital, School of Medicine, Zhejiang University, Hangzhou, Zhejiang, China

${ }^{2}$ Department of Hematology, People's Hospital of Quzhou, Quzhou, Zhejiang, China

${ }^{3}$ Department of Hematology, The Second Affiliated Hospital of Nanchang University, Nanchang, Jiangxi, China

*These authors have contributed equally to this work

Correspondence to: Zhen Cai, email: caiz@zju.edu.cn

Keywords: interleukin-32, IL-6, multiple myeloma, bone marrow stromal cells

Received: March 14, $2017 \quad$ Accepted: August 17, $2017 \quad$ Published: October 07, 2017

Copyright: Lin et al. This is an open-access article distributed under the terms of the Creative Commons Attribution License 3.0 (CC BY 3.0), which permits unrestricted use, distribution, and reproduction in any medium, provided the original author and source are credited.
\end{abstract}

\section{ABSTRACT}

Multiple myeloma (MM) is a malignant plasma disease closely associated with inflammation. In MM bone marrow microenvironment, bone marrow stromal cells (BMSCs) are the primary source of interleukin-6 (IL-6) secretion, which promotes the proliferation and progression of MM cells. However, it is still unknown how the microenvironment stimulates BMSCs to secrete IL-6. Interleukin-32 (IL-32) is a newly identified pro-inflammatory factor. It was reported that in solid tumors, IL-32 induces changes in other inflammatory factors including IL-6, IL-10, and TNF-a. The aim of this study was to investigate the expression of IL-32 and the role of IL-32 in the MM bone marrow microenvironment. Our data illustrate that MM patients have higher expression of IL-32 than healthy individuals in both bone marrow and peripheral blood. We used ELISA and qRT-PCR to find that malignant plasma cells are the primary source of IL-32 production in MM bone marrow. ELISA and Western blot analysis revealed that recombinant IL-32a induces production of IL- 6 in BMSCs by activating NF-KB and STAT3 signaling pathways, konckdown of IL-32 receptor PR3 inhibit this process. Knockdown of IL-32 by shRNA decreased the proliferation in MM cells that induced by BMSCs. In conclusion, IL-32 secreted from MM cells has paracrine effect to induce production of IL-6 in BMSCs, thus feedback to promote MM cells growth.

\section{INTRODUCTION}

Multiple myeloma (MM), characterized by the accumulation of malignant plasma cells and the production of monoclonal immunoglobulin, is an incurable malignant blood disease that originates from the B cell lineage and accounts for approximately $21 \%$ of deaths from hematological malignancies in the US [1-3]. MM development is primarily dependent on the bone marrow (BM) microenvironment. Direct contact with cells in the
$\mathrm{BM}$ microenvironment, such as bone marrow stromal cells (BMSCs), macrophages, osteoclasts and endothelial cells, induces MM cell growth, proliferation, invasion and metastasis, as do the cytokines and the chemokines in the microenvironment [4-6]. MM is closely associated with inflammation. Patients with autoimmune disease, a history of infection, and other inflammatory diseases have a higher incidence of MM and monoclonal gammopathy of undetermined significance (MGUS) [7]. Researches showed that inflammatory mediators, such as interleukin 
6 (IL-6), Toll-like receptor (TLR), signal transducer and activator of transcription 3 (STAT3), and nuclear factor$\kappa \mathrm{B}(\mathrm{NF}-\kappa \mathrm{B})$, are critical in the transformation from inflammation to tumor [8, 9]. Previous studies have demonstrated that MM cells are modified by BMSCs that form an inflammatory microenvironment that benefits the MM cells in the BM [10, 11]. Jego et al. reported that IL6 , which is mainly produced by BMSCs, plays a key role in the proliferation and progression induced by repeated infections in MM [12]. However, how inflammation induces BMSCs in the MM BM microenvironment to secrete IL-6 remains unknown.

Recent studies have indicated that interleukin 32 (IL-32), a newly defined pro-inflammatory cytokine that was initially discovered from natural killer cells and is also named natural killer 4 (NK-4) [13], increases the secretion of inflammatory factors such as Interleukin-6 (IL-6), IL$1 \beta$ and TNF- $\alpha$, thus inducing an inflammation 'cascade amplification effect' $[14,15]$.
IL-32 is a unique cytokine with different isoforms that are required to activate specific cells and have diverse effects on different cells [16-18]. Studies in solid tumors, such as gastric cancers, pancreatic cancers and renal carcinomas, have found high expression of IL-32, suggesting that this cytokine is an independent prognostic factor [19-21]. Howener, in HeLa cells, overexpression of IL-32 increases cell apoptosis, and impairs cell growth and migration [22]. Moreover, in hematological malignancies, IL-32 is remarkably increased in patients with myelodysplastic syndrome (MDS), whereas patients with chronic myelomonocytic leukemia (CMML) have markedly reduced expression of IL-32 [23]. Thus, the role and function of IL-32 in tumors are still controversial. In addition, the expression of IL32 in MM remains uncovered, and it is still unknown whether IL-32 has a pro-inflammatory function in the MM BM microenvironment formed by BMSCs and other cells.
A

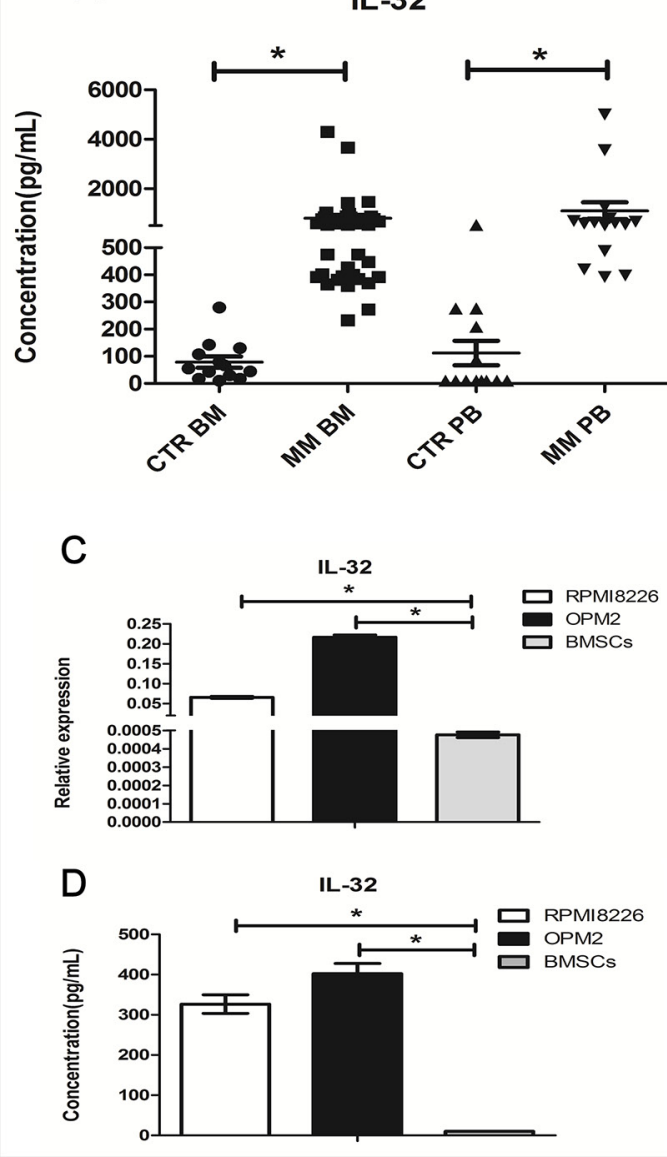

B
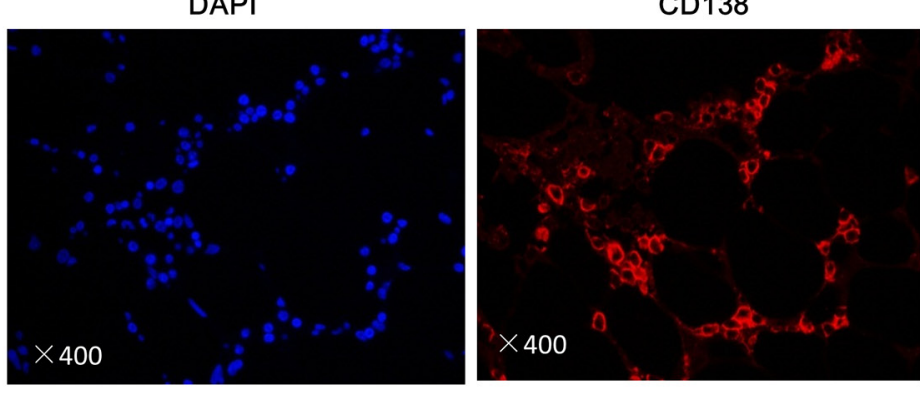

IL-32
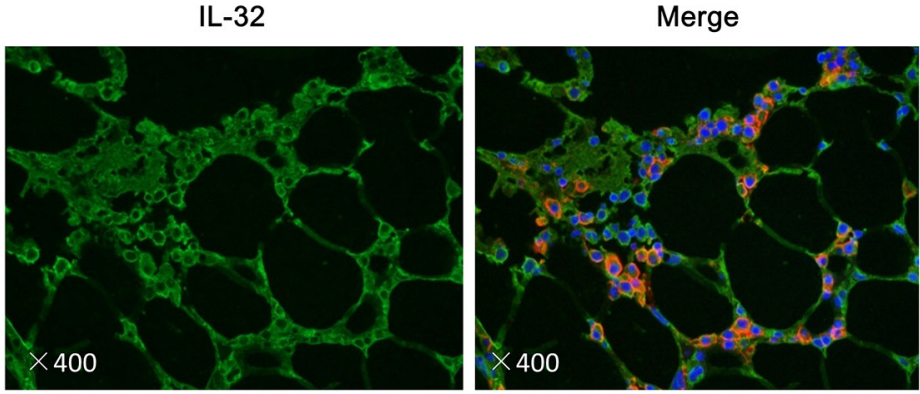

E

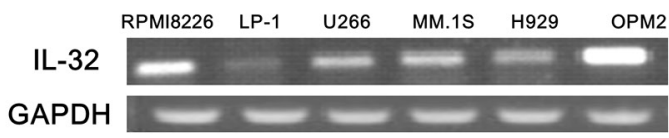

MM cell lines

Figure 1: Expression of IL-32 in MM patients, human myeloma cells and BMSCs. (A) Expression of IL-32 in BM and PB, MM patients are compared to normal healthy donors (CTR), measured by ELISA. (B) Immunofluorescence analysis of MM patients BM biopsies with anti-CD138, anti-IL-32 antibodies (magnification: $\times 400$ ). (C) PCR analysis of the expression of IL-32 in RPMI8226, OPM2 and BMSCs. BMSCs obtained from different MM patient $(n=9)$. (D) Expression of soluble IL-32 in RPMI8226, OPM2 and BMSCs, measured by ELISA; BMSCs obtained from different MM patient (n=9). (E) PCR analysis of the expression of IL-32 in MM cell lines. * $p<0.05$. 
In this study, we analyzed the expression of IL32 in MM cells and in the MM BM microenvironment, and explored the role and mechanism of IL-32 in the inflammatory factors network and the proliferation of MM cells.

\section{RESULTS}

\section{Expression of IL-32 in human myeloma cells and BMSCs}

As a cytokine, we first detected soluble IL-32 in the BM of both newly diagnosed MM patients $(n=38)$ and normal healthy donors $(n=13)$ by ELISA. As shown in Figure 1A, MM patients exhibited significantly higher secretion of soluble IL-32 compared to healthy controls (798.2 $\pm 132.1 \mathrm{pg} / \mathrm{mL}$ vs $79.88 \pm 20.54 \mathrm{pg} / \mathrm{mL}, p<0.05)$. In peripheral blood (PB), the expression of IL-32 in MM patients $(n=15)$ was higher than that in healthy donors $(\mathrm{n}=15)$ as well $(1103 \pm 344.7 \mathrm{pg} / \mathrm{mL}$ vs $111.8 \pm 45.13 \mathrm{pg} /$ $\mathrm{mL}, p<0.05$ ) (Figure 1A). Next, immunofluorescence analysis of human BM biopsies showed that both $\mathrm{CD} 138^{+}$ and CD138- cells in MM BM express IL-32 (Figure 1B). Finally, we checked the expression of IL-32 in MM cell lines and human BMSCs using qRT-PCR and ELISA. The results suggested that MM cell lines also expressed IL-32. Some of the cell lines like LP-1, H929 expressed relatively low IL-32, while RPMI8226 and OPM2 had extremely high expression of IL-32 among the rest (Figure 1E). RPMI8226 and OPM2 express approximately 50-100 folds higher levels of IL-32 mRNA than BMSCs (Figure 1C, 1D).

As the MM BM microenvironment contains both CD $138^{+}$malignant plasma cells and CD138- non-plasma cells, we tried to examine the cell sources that contributed to the majority of the IL-32 secretion. qRT-PCR was used to assess gene expression, and ELISA was applied for the detection of soluble IL-32 in primary CD $138^{+}$cells and CD138 cells isolated from 10 newly diagnosed untreated MM patients. The former, considered as primary MM cells, had a relatively high expression of IL-32 compared to the latter (Figure 2A, 2B). As IL-32 has different isoforms, furthermore, we detected 5 samples from the above by qRT-PCR, found that the most prevalent expressed isoform in primary MM cells was IL-32 $\alpha$ (Figure 2C).

\section{IL-32 $\alpha$ induces production of IL-6 in MM BMSCs}

To determine the effect of IL-32 in the MM BM microenvironment, a cytokine array was applied to assay cytokines and chemokines induced or reduced by rIL-32 $\alpha$. As shown in Figure 3, not only the production of IL-6 in BMSCs, but also the expression of MIP- $1 \alpha$ and MIP-1 $\beta$ increased. In addition, CCL-5, IL-10 and VEGF decreased.
To verify the result of the cytokine array, we stimulated BMSCs with rIL-32 $\alpha$ in a concentrarion escalating manner $(20 \mathrm{ng} / \mathrm{mL}, 40 \mathrm{ng} / \mathrm{mL}, 80 \mathrm{ng} / \mathrm{mL}$ and $160 \mathrm{ng} / \mathrm{mL})$ and in a time escalating manner $(24 \mathrm{~h}, 48$ $\mathrm{h}$ and $72 \mathrm{~h}$ ). ELISA was applied to detect soluble IL-6 secreted into the culture media. As shown in Figure 4A, compared to control, $20 \mathrm{ng} / \mathrm{mL}$ rIL-32 $\alpha$ significantly induced BMSCs to express IL-6 (e.g., at $24 \mathrm{~h}$, $335.3 \pm 11.2 \mathrm{pg} / \mathrm{mL}$ vs $106.8 \pm 9.7 \mathrm{pg} / \mathrm{mL}, p<0.05)$. As the concentration of rIL-32 $\alpha$ increased, the release of IL- 6 by BMSCs achieved higher levels approximately 3 to 8 fold higher than normal. However, there were no specific time dependent changes $(p>0.05)$ (Figure 2A), and rIL-32 $\alpha$ did not induce TNF- $\alpha$ secretion in BMSCs (Figure 4B). As BMSCs have a basement secretion of IL-6, we tried to determine whether the increase in IL-6 secretion was due to the proliferation of BMSCs. We used CCK8 assay to evaluate the growth of BMSCs. The results showed that rIL-32 $\alpha$ did not promote the proliferation of BMSCs directly (Figure 4E). Further, we examined BMSCs obtained from different individuals $(n=9)$, and $66.7 \%$ showed a positive effect in the stimulation of rIL-32 $\alpha$ with an appropriate concentration $(20 \mathrm{ng} / \mathrm{mL}, 40 \mathrm{ng} / \mathrm{mL})$ for 24 h (Figure 4C). We also stimulated MM cell lines with rIL$32 \alpha$. MM cell lines were not expected to secrete as much IL-6 as BMSCs, nor did they when stimulated with rIL$32 \alpha$ (Figure 2A).

As IL-32 may be primarily from the plasma cells, we next co-cultured BMSCs with MM cell lines (BMSCs in the lower chamber, MM cell lines in the Transwell inserts, pore size: $0.4 \mu \mathrm{m}$ ) to determine the functions of MM cells secreted IL-32. We compared normal MM cells to IL-32-knockdown MM cells and found that RPMI8226 cells induced BMSCs to express and secrete higher levels of IL-6 (360.8 $\pm 28.4 \mathrm{pg} / \mathrm{mL}$ vs $177.3 \pm 9.4 \mathrm{pg} / \mathrm{mL}, p<0.05)$. Knockdown of IL-32 in MM cells by shRNA reduced the enhancing effect toward BMSCs $(246.7 \pm 10.9 \mathrm{pg} / \mathrm{mL}$ vs $360.8 \pm 28.4 \mathrm{pg} / \mathrm{mL}, p<0.05)$. Similar results were observed in OPM2 cells as well as in RPMI8226 cells (Figure 4D).

\section{IL-32 $\alpha$ activates the NF- $\mathrm{KB}$ and STAT3 signaling pathways in BMSCs}

Studies have demonstrated that, in the MM BM microenvironment, $\mathrm{NF}-\kappa \mathrm{B}$ and STAT3 transcriptional activities are induced by cytokines, and then collaborate to induce IL-6.

Western blotting was applied to detect a possible inflammation signaling pathway in BMSCs induced by rIL-32 $\alpha$. As shown in Figure 5A, NF- $\kappa$ B and STAT3 pathways were activated through upregulation of the phosphorylation of p65NF- $\mathrm{B}$ and STAT3 Ser-727, but no significant changes in the phosphorylation of STAT3 Tyr-705 or p38MAPK were observed. Subsequently, we detected the phosphorylation of $\mathrm{p} 65 \mathrm{NF}-\kappa \mathrm{B}$ and STAT3 Ser-727 induced by rIL-32 $\alpha$ in a concentration- 


$$
\text { A }
$$

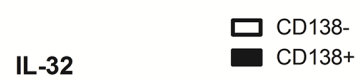

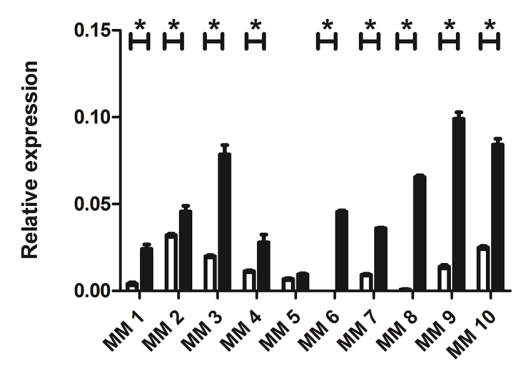

B

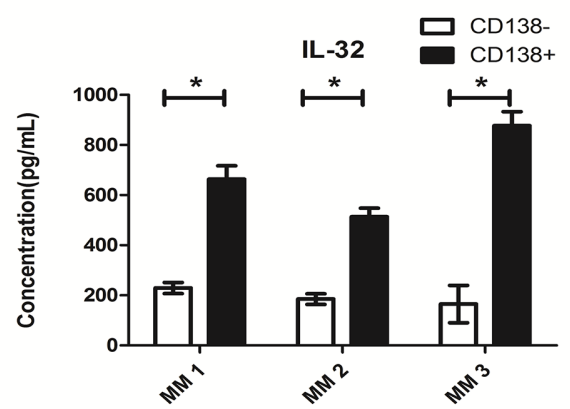

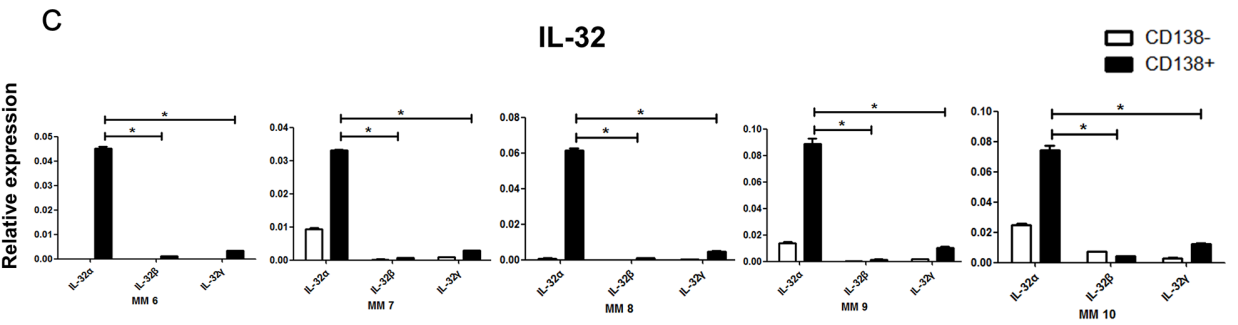

Primary cells

Figure 2: Expression of IL-32 in primary MM cells. (A) qRT-PCR analysis of the expression of IL-32 in primary CD138 and CD138 cells isolated from MM patients. (B) Primary CD138 ${ }^{+}$and CD138 cells isolated from MM patients were cultured in vitro for $12 \mathrm{~h}$ (inclusion criteria: cell apoptosis $<50 \%$, detected by flow cytometry), ELISA was applied to detect soluble IL-32 in the culture medium. (C) qRT-PCR analysis of the expression of different IL-32 isoforms (IL-32 $\alpha$, IL-32 $\beta$, IL-32 $\gamma$ ) in primary CD138 ${ }^{+}$and CD138 cells isolated from MM patients. ${ }^{*} p<0.05$.

A

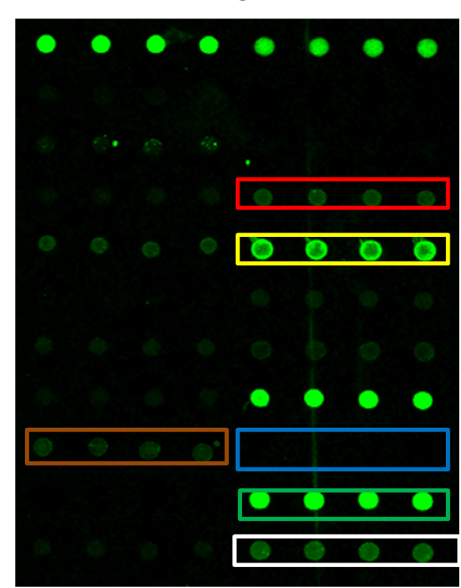

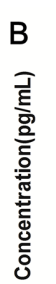

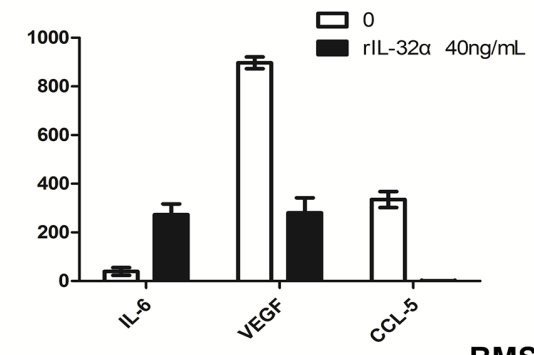

rIL-32 $40 \mathrm{ng} / \mathrm{mL}$
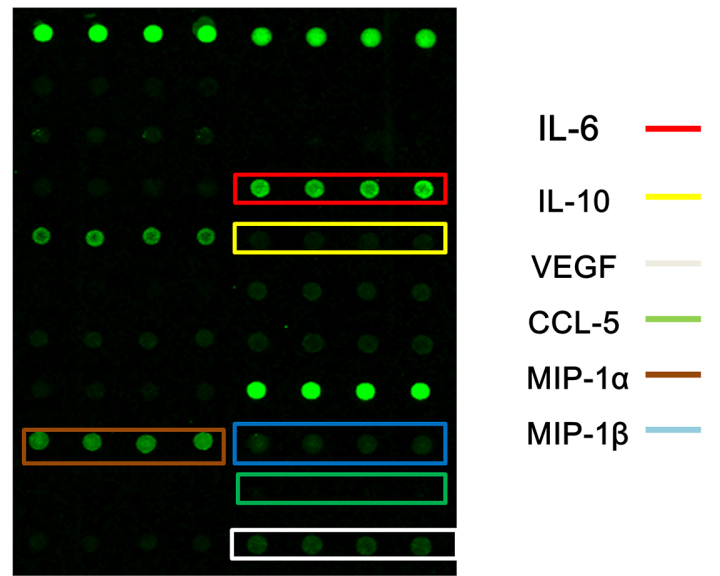

VEGF

CCL-5

MIP-1 $1 \alpha-$

MIP-1 $1 \beta=$

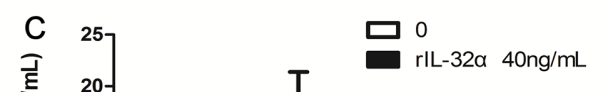

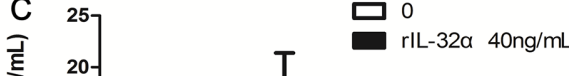

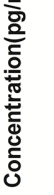

BMSCs

Figure 3: Cytokine array analysis in BMSCs induced by rIL-32a. (A) Cytokines and chemokines changes in BMSCs with or without $40 \mathrm{ng} / \mathrm{mL}$ rIL-32 $\alpha$ stimulation. These images show the results of BMSCs obtained from one patient. (B) (C) Total analysis of cytokines and chemokines in BMSCs obtained from different patients $(n=4)$. 
escalating manner (20 ng/mL and $40 \mathrm{ng} / \mathrm{mL})$ and in a time-escalating manner $(1 \mathrm{~h}$ and $2 \mathrm{~h}$ ). The results showed that phosphorylation of $\mathrm{p} 65 \mathrm{NF}-\kappa \mathrm{B}$ and STAT3 Ser-727 increased as the concentration of rIL- $32 \alpha$ rose, and the stimulation was consistent (Figure 5B, 5C). To confirm that, we used NF- $\kappa$ B inhibitor QNZ $(10 \mu \mathrm{M} / \mathrm{mL})$ and STAT3 inhibitor BP-1-102 $(10 \mu \mathrm{M} / \mathrm{mL})$ to block the activation of these two inflammation signaling pathways. As shown in Figure 5D, rIL-32 $\alpha+$ QNZ treated group and rIL-32 $\alpha+$ BP-1-102 treated group both decreased the production of IL-6 in BMSCs compared to the group that treated with rIL-32 $\alpha$ alone $(411.75 \pm 5.39 \mathrm{pg} / \mathrm{mL}$, $133.18 \pm 23.65 \mathrm{pg} / \mathrm{mL}$ vs $1033.12 \pm 100.71 \mathrm{pg} / \mathrm{mL}, p<0.05)$.

\section{Expression of PR3 in BMSCs}

We examined the expression of proteinase 3 (PR3), a binding protein of extracellular IL-32 that increase its activity, using qRT-PCR. As shown in Figure 6A, BMSCs express significant higher levels of PR3 mRNA compared to MM cell lines.

To verify the participation of the NF- $\kappa$ B and STAT3 signaling pathways in IL-32 and BMSCs-mediated production of IL-6, we inhibited the expression of PR3 in BMSCs using siRNA. In the BMSCs group with PR3 knockdown, the production of IL- 6 after stimulation with rIL-32 $\alpha$ decreased markedly compared to the
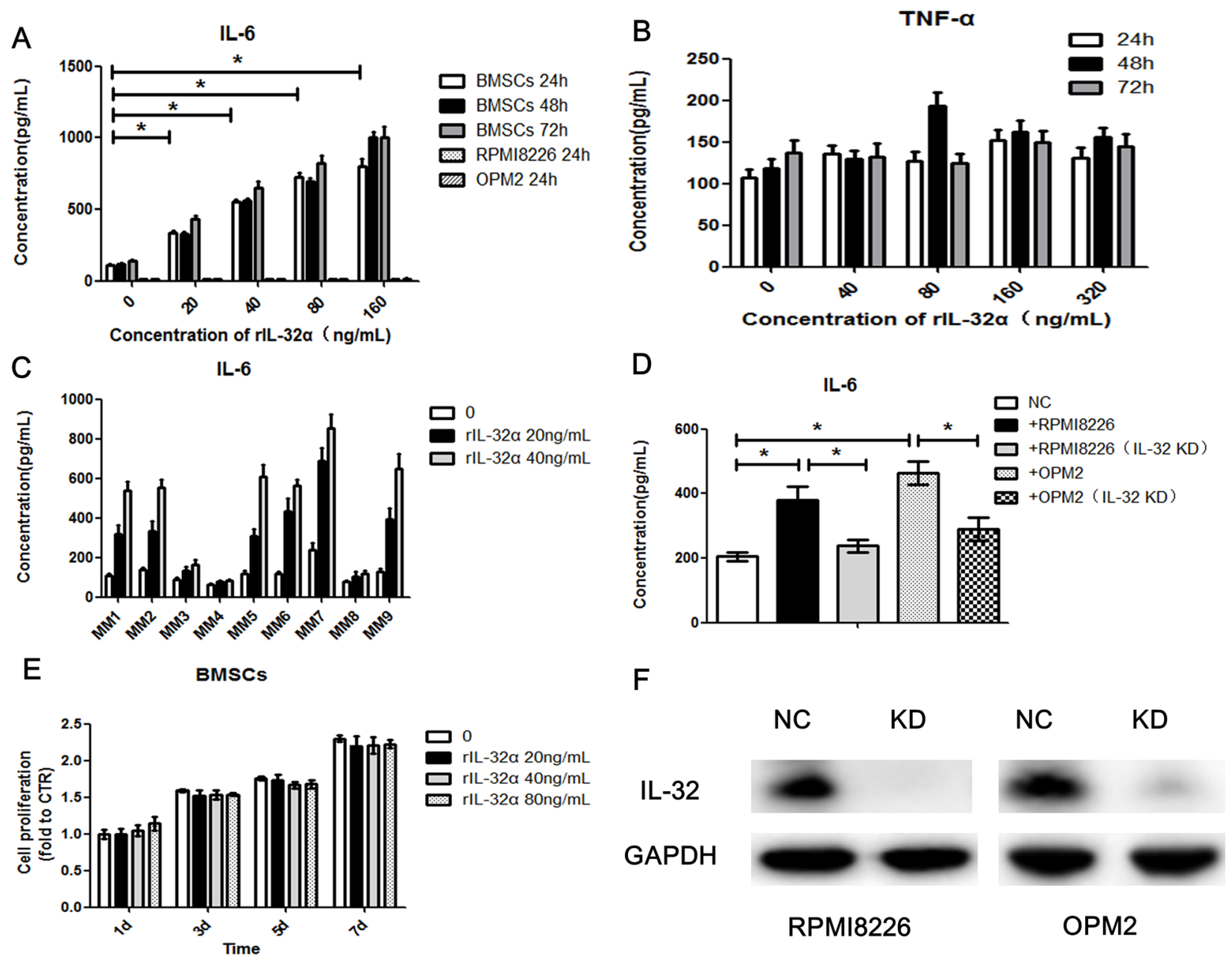

Figure 4: IL-32 $\alpha$ induces production of IL-6 in MM BMSCs. (A) Concentration of IL-6 in BMSCs in the presence of 0-160 ng/ $\mathrm{mL}$ rIL-32 $\alpha$, stimulated for 24, 48, and $72 \mathrm{~h}$. BMSCs obtained from one MM patient, repeated in three independent experiments, measured by ELISA. (B) Concentration of TNF- $\alpha$ in BMSCs in the presence of 0-320 ng/mL rIL-32 $\alpha$, stimulated for 24, 48 and $72 \mathrm{~h}$. Samples obtained from one MM patient, repeated in three independent experiments, measured by ELISA. (C) Concentration of IL-6 in BMSCs in the presence of $0-40 \mathrm{ng} / \mathrm{mL}$ rIL-32 $\alpha$, stimulated for $24 \mathrm{~h}$, BMSCs obtained from different patients, and 6 in 9 (66.7\%) showed positive effects, measured by ELISA. (D) Concentration of IL-6 in BMSCs co-cultured with IL-32 high-expression MM cell lines, with or without IL-32 knockdown; BMSCs were co-cultured with MM cells in a 24-well Transwell plate, repeated in three independent experiments, measured by ELISA. (E) Cell proliferation of BMSCs in the presence of 0-80 ng/mL rIL-32 $\alpha$, stimulated for 1, 3, 5 and $7 \mathrm{~d}$; cells were cultured in 96 well plates, repeated in three independent experiments, measured by CCK8 assay. (F) Identification of IL-32 knockdown MM cell lines, Western blot analysis. 
group without PR3 knockdown $(398.6 \pm 56.92 \mathrm{pg} / \mathrm{mL}$ vs $665.7 \pm 73.13 \mathrm{pg} / \mathrm{mL}, 24 \mathrm{~h}, p<0.05)$, but it was still higher than the group that was not stimulated $(306.6 \pm 42.14 \mathrm{pg} /$ $\mathrm{mL}$ ) (Figure 6B). Similarly, knockdown of PR3 reduced the activation of the NF- $\kappa$ B and STAT3 signaling pathways induced by rIL-32 $\alpha$ compared to the group without PR3 knockdown (Figure 6D).

\section{IL-32 $\alpha$ promoted the proliferation of MM cells in the tumor microenvironment}

The role of IL-6 in MM as a growth and survival factor is unambiguous. As IL-32 induced the production of IL-6 in BMSCs, we tried to verify the biological function of IL-32 toward MM cells in the BM microenvironment. First, rIL-32 $\alpha$ was used to stimulate both IL-32 low-expression and high-expression MM cell lines when cultured with normal medium, it seemed not to promote the proliferation of MM cells directly (Figure 7A), nor did we detect any changes in apoptosis (data not shown). Second, BMSCs conditioned medium (BCCM) was used to culture IL-32 low-expression MM cell lines (H929 and LP-1) for $72 \mathrm{~h}$ and CCK8 assay was applied to analyze the proliferation of MM cells. The rIL-32 $\alpha$-treated BCCM significantly promoted the proliferation of $\mathrm{H} 929$ cells and LP-1 cells compared to the non-treated BCCM (e.g., H929, rIL-32 $\alpha 40 \mathrm{ng} / \mathrm{mL}$ $72 \mathrm{~h}, 7.11 \pm 0.18$ vs $5.32 \pm 0.26, p<0.05$ ) (Figure $7 \mathrm{~B}, 7 \mathrm{C}$, Supplementary Figure 1). Then, we co-cultured IL-32 highexpression MM cell lines (RPMI8226 and OPM2) with BMSCs as mentioned above with or without knockdown of IL-32. As shown in Figure 7D and 7E, IL-32-knockdown RPMI8226 cells and OPM2 cells showed a lower proliferation rate in the imitated $\mathrm{BM}$ microenvironment compared to normal MM cells (e.g., RPMI8226, 72
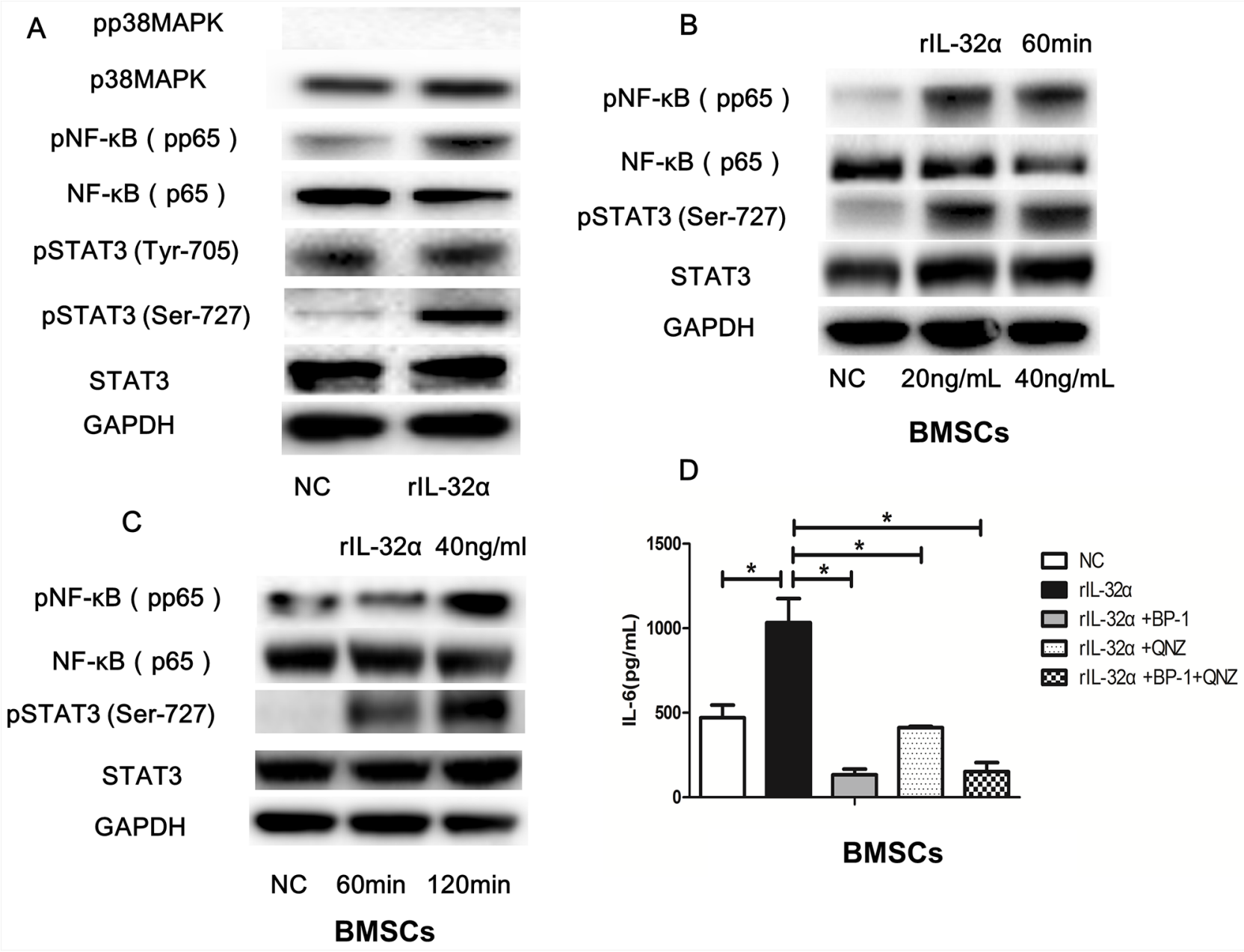

BMSCs

Figure 5: IL-32 $\alpha$ activates the NF- $\mathrm{B}$ and STAT3 signaling pathways in BMSCs. (A) Western blot analysisof $\mathrm{p} 38$, NF- $\kappa \mathrm{B}$ and STAT3 signaling pathway and in BMSCs with or without $40 \mathrm{ng} / \mathrm{mL}$ rIL-32 $\alpha$ stimulation for $60 \mathrm{~min}$. (B) Western blot analysisof NF- $\kappa \mathrm{B}$ and STAT3 signaling pathwaysin BMSCs with 20-40 ng/mL rIL-32 $\alpha$ stimulation for $60 \mathrm{~min}$. (C) Western blot analysisof NF- $\mathrm{kB}$ and STAT3 signaling pathwaysin BMSCs with $40 \mathrm{ng} / \mathrm{mL}$ rIL-32 $\alpha$ stimulation for 60-120 min. (D) Concentration of IL-6 in BMSCs in the presence of $40 \mathrm{ng} / \mathrm{mL}$ rIL-32 $\alpha$ for $24 \mathrm{~h}$, with or without NF- $\kappa$ B inhibitor QNZ $(10 \mu \mathrm{M} / \mathrm{mL})$, STAT3 inhibitor BP-1-102 $(10 \mu \mathrm{M} / \mathrm{mL})$, measured by ELISA; BMSCs obtained from one MM patient, repeated in three independent experiments. ${ }^{*} p<0.05$. 
h,7.24 \pm 0.20 vs $8.82 \pm 0.34, p<0.05$ ); when rIL-32 $\alpha$ (40ng/ $\mathrm{mL}$ ) was applied to rescue the IL-32-knockdown MM cells in the co-culture system, the proliferation rate increased again (e.g., RPMI8226, $72 \mathrm{~h}, 8.62 \pm 0.26$ vs $7.24 \pm 0.20$, $p<0.05)$. However, there was not much difference in growth between the IL-32-knockdown cell lines and the normal cell lines when cultured alone. Finally, to confirm that the increased proliferation was due to the production of IL-6 in BMSCs, we repeated the experiments that were applied for LP-1 and H929 before in IL-6 dependent MM cell line ANBL-6, the result (Figure 7F) showed that rIL$32 \alpha$-treated BCCM had nearly the same effect compared to normal medium with rIL-6 (20ng/mL) (e.g., ANBL-6, rIL-32 $\alpha 40 \mathrm{ng} / \mathrm{mL} 72 \mathrm{~h}, 4.60 \pm 0.17$ vs $5.65 \pm 0.18)$, IL-6 neutralization antibodies $(20 \mathrm{ng} / \mathrm{mL})$ significantly inhibited the proliferation of ANBL- 6 cells cultured in BCCM (e.g., ANBL-6, rIL-32 $\alpha$ 40ng/mL+IL-6 neutral 72h, 2.64 \pm 0.51 vs $4.60 \pm 0.17, p<0.05)$. These data suggested that IL-32 may be more likely to have paracrine effects in the BM microenvironment than MM cells themselves, and then a feedback mechanism supports MM cells.

\section{DISCUSSION}

IL-32 is a novel pro-inflammatory cytokine that is found to exist in nine different isoforms, including IL-32 $\alpha$, IL-32 $\beta$, IL-32 $\gamma$, IL-32 $\delta$, IL-32 $\varepsilon$, IL-32 $\zeta$, IL-32 $\eta$ and IL$32 \theta$ [16]. Kim et al. first reported its biological function in 2005 [24]. Accumulatiing evidence indicates that IL-32 is a pluripotent cytokine with diverse functions [25-28]. NK-4 coding protein was initially assumed to be a secreted protein, but some newly found isoforms lack of a putative signal peptide, and the amount secreted from cells is small $[16,17]$. Hasegawa reported that IL-32 might be released from intestinal epithelial cells via a non-classical secretory route, such as multi-vesicular and exosomal secretion [29]. Studies have also demonstrated that intracellular IL-32 interferes with Paxillin-FAK binding by resembling the
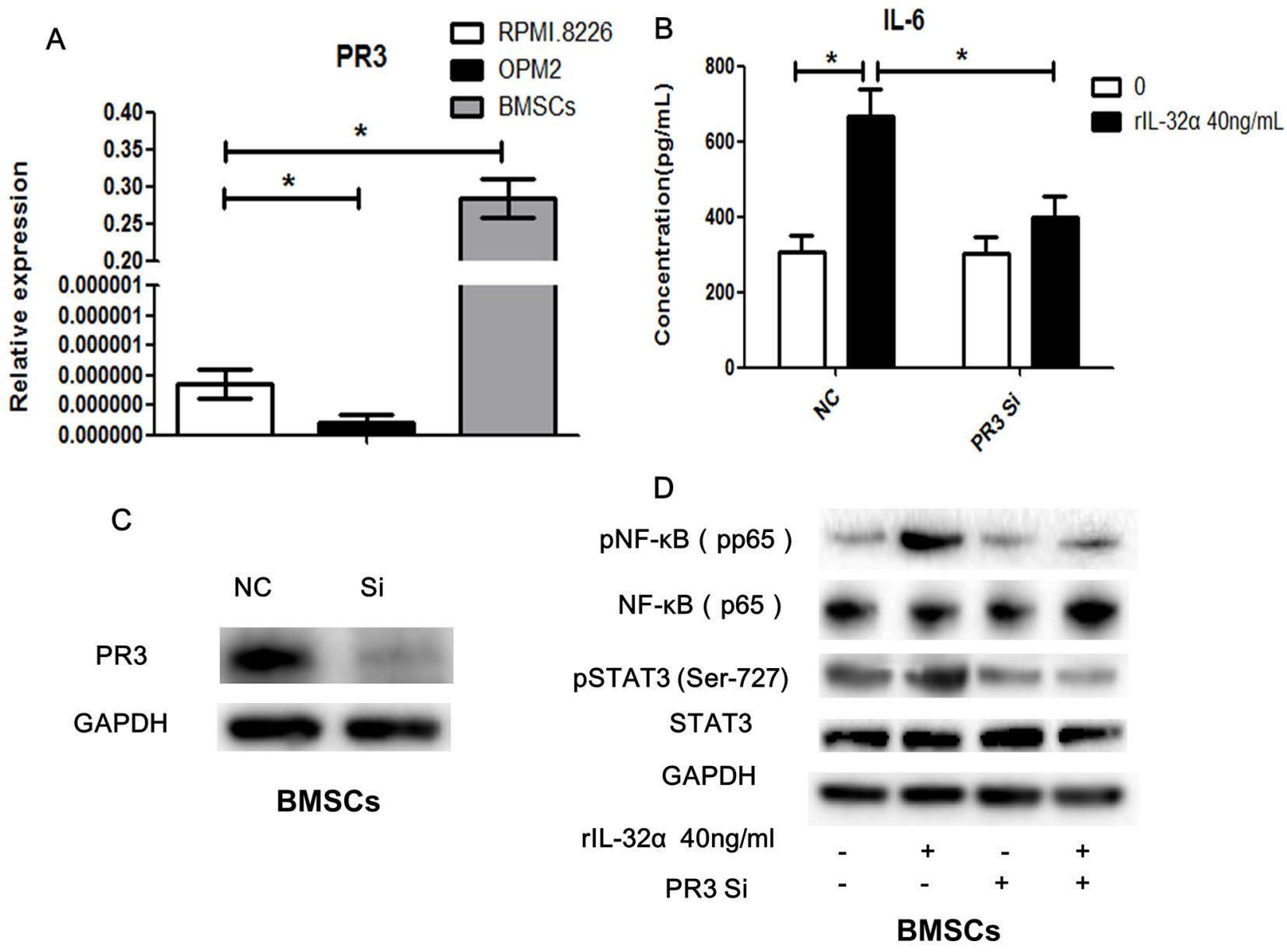

Figure 6: PR3 involved in IL-32 induced IL-6 production in BMSCs. (A) qRT-PCR analysis of the expression of PR3 in BMSCs and MM cells. (B) Concentration of IL-6 in BMSCs in the presence of $40 \mathrm{ng} / \mathrm{mL}$ rIL-32 $\alpha$ for $24 \mathrm{~h}$, with or without PR3 knockdown, BMSCs obtained from one MM patient, repeated in three independent experiments, measured by ELISA. (C) Identification of PR3 knockdown BMSCs. (D) Western blot analysisof NF- $\mathrm{kB}$ and STAT3 signaling pathwaysin BMSCs in the presence of $20 \mathrm{ng} / \mathrm{mL} \mathrm{rIL}-32 \alpha$ for $60 \mathrm{~min}$, with or without PR3 knockdown. ${ }^{*} p<0.05$. 
FAT region, where as extracellular IL-32 binds to PR3 [30]. Therefore, it seems that IL-32 has both intracellular and extracellular biological functions according to the differential uptake by cells and the different isoforms.

Numerous studies have been published on the role of IL-32 in cancers and cancer- related malignancies. It is still controversial because IL-32 exhibits opposite effects in different tumors. In human stomach cancer and pancreatic cancer patients, IL-32 is highly expressed compared with healthy individuals $[20,31]$. In renal cell carcinoma, a previous study showed that IL-32 overexpression was associated with high recurrence rates, low recurrence free survival and overall survival, and thus may be a new prognostic factor [21]. Tsai and co-workers also reported that high expression of IL-32 in gastric cancer was positively correlated with tumor metastasis and poor prognosis [19]. In this study, we examined the expression of IL-32 in peripheral blood and bone marrow and found that MM patients have higher expression of IL32 compared to healthy individuals. Further, we confirmed that the production of IL-32 in MM patients was primarily from the $\mathrm{CD} 138^{+}$malignant plasma cells rather than the CD138- cells in the BM microenvironment. In addition, IL-32 is also associated with inflammatory diseases and autoimmune diseases. In COPD, it was reported that IL32 was linked to pathologic changes in patients. Another study demonstrated that in serum from myasthenia gravis patients, IL-32 $\alpha$ was significantly increased [32]. As MM is closely related with autoimmune disease and chronic inflammation, high expression of IL-32 in MM cells may also contribute to the evolution of malignant plasma cells, which needs to be thoroughly explored.
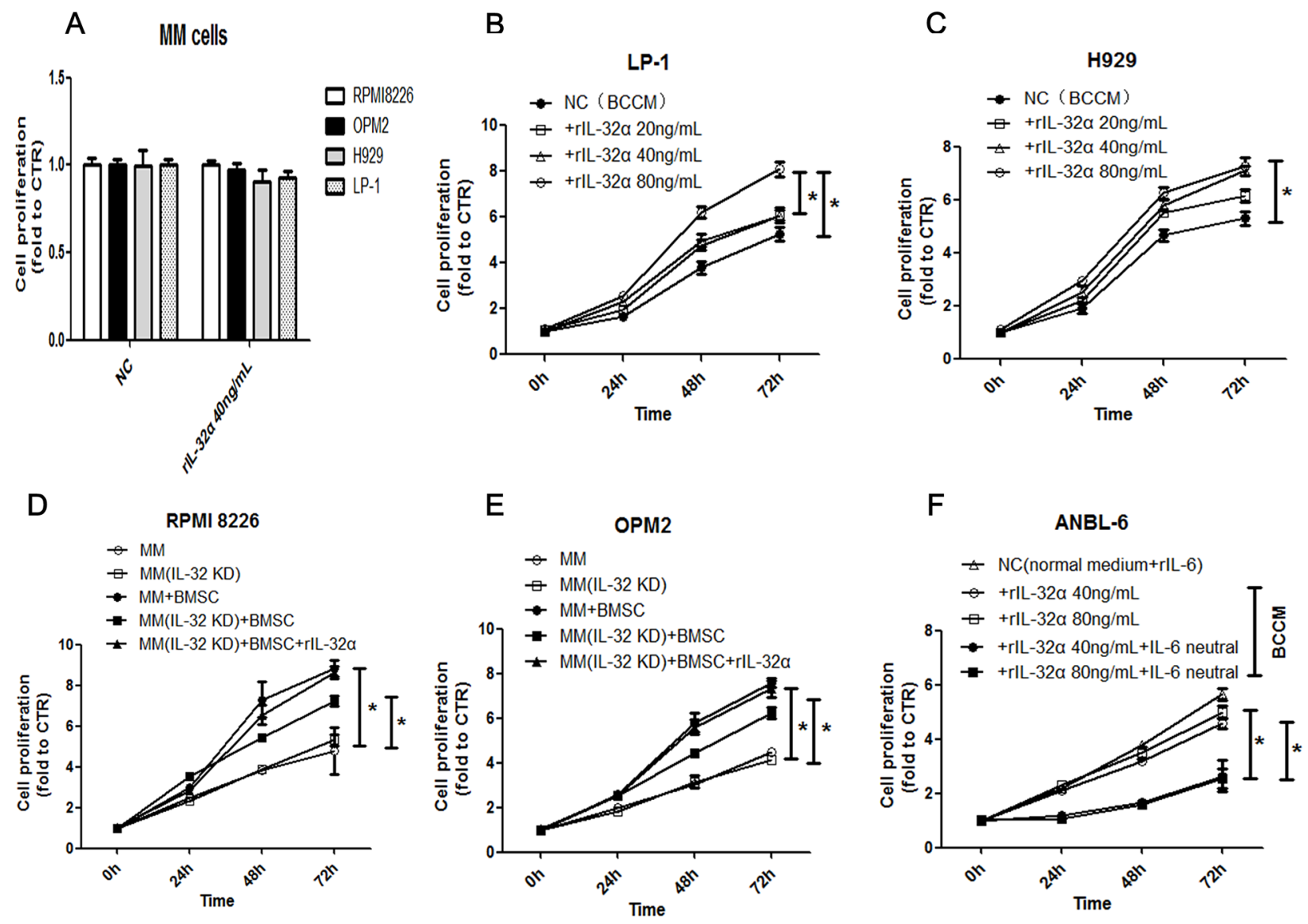

Figure 7: IL-32 $\alpha$ promotes the proliferation of MM cells in the tumor microenvironment. (A) Cell proliferation of MM cell lines during exposure to $40 \mathrm{ng} / \mathrm{mL}$ rIL-32 $\alpha$ for $24 \mathrm{~h}$. Repeated in three independent experiments, measured by CCK8. (B) (C) Cell proliferation in IL-32 low-expression MM cell lines, H929 and LP-1, cultured in BCCM stimulated by $0-80 \mathrm{ng} / \mathrm{mL}$ rIL-32 $\alpha$ for 24,48 and $72 \mathrm{~h}$. MM cells were cultured in 96-well plates. Repeated in three independent experiments, measured by CCK8. (D) (E) Cell proliferation in IL-32 high-expression MM cell lines, RPMI8226 and OPM2, cultured alone or co-cultured with BMSCs for 24, 48, and $72 \mathrm{~h}$, with or without IL-32 knockdown. rIL-32 $\alpha$ rescue concentration was 40ng/mL. MM cells were co-cultured with BMSCs in 24-well plates and transferred to 96 -well plates to be assayed. Repeated in three independent experiments, measured by CCK8. (F) Cell proliferation in IL-6 dependent MM cell line ANBL-6, cultured in BCCM stimulated by $0-80 \mathrm{ng} / \mathrm{mL}$ rIL-32 $\alpha$ for 24 , 48 and 72 h, with or without IL-6 neutralization antibodies $(20 \mathrm{ng} / \mathrm{mL})$; cells in control group were cultured in normal medium with rIL-6 (20ng/mL); MM cells were cultured in 96-well plates. Repeated in three independent experiments, measured by CCK8. 
IL-32 $\alpha$ is the most abundant clone among all the IL-32 isoforms, and it is expressed in various cells such as NK cells, T cells and monocytes [24], we also found that the majority expressed in the primary MM cells was IL-32 $\alpha$. Studies have demonstrated that, unlike IL-32 $\beta$ and IL-32 $\gamma$, over-expression of IL-32 $\alpha$ does not cause cell death directly but increases the NK cell-mediated killing in chronic myeloid leukemia cells [33, 34]. More importantly, intracellular IL-32 $\alpha$ induces STAT3 Ser-727 phosphorylation by binding with PMA-activated PKC $\varepsilon$ and STAT3 and thus enhances IL-6 production [35], while the other two isoforms, IL-32 $\beta$ and IL-32 $\gamma$, inactivate the STAT3 signaling pathway $[36,37]$. On the other hand, PR3 binds specifically to extracellular IL-32 $\alpha$ with high affinity $[30,38]$. For the purpose of identifying the function of IL-32 $\alpha$ as a secreted cytokine in MM, our studies showed that rIL-32 $\alpha$ induced the production of IL- 6 in BMSCs by activating the NF- $\kappa \mathrm{B}$ and STAT3 signaling pathways. We also found that BMSCs co-cultured with high IL32- expressing MM cells produced more IL-6 compared to those co-cultured with IL-32- knockdown MM cells, indicating that MM cell secretion of IL-32 may have the same biological function as rIL-32 $\alpha$. It is well established that in the MM BM microenvironment, BMSCs are the primary source of IL-6, which has strong paracrine proliferation stimulation effects on the MM cells [39]. IL-6 production induced by cooperation of NF- $\mathrm{KB}$ and STAT3 signaling can provide feedback to keep these two signaling pathways consistently activated, thus promoting an inflammation 'cascade amplification effect' [40-42]. Therefore, it seems to be very important to find the key that initializes this process. Our study suggested that IL32 secreted from MM cells may 'start' or at least enhance this procedure by activating NF- $\kappa \mathrm{B}$ and STAT3 signaling pathways. We also confirmed that BMSCs produced-IL-6, which was induced by IL-32 $\alpha$ feedback to promote the proliferation of MM cells. In agreement with a previous study, we have not yet found any evidence yet that IL$32 \alpha$ has a direct effect on MM cells (apoptosis and proliferation).

PR3, which exists in both soluble form and cell surface, is a serine protease derived from neutrophil

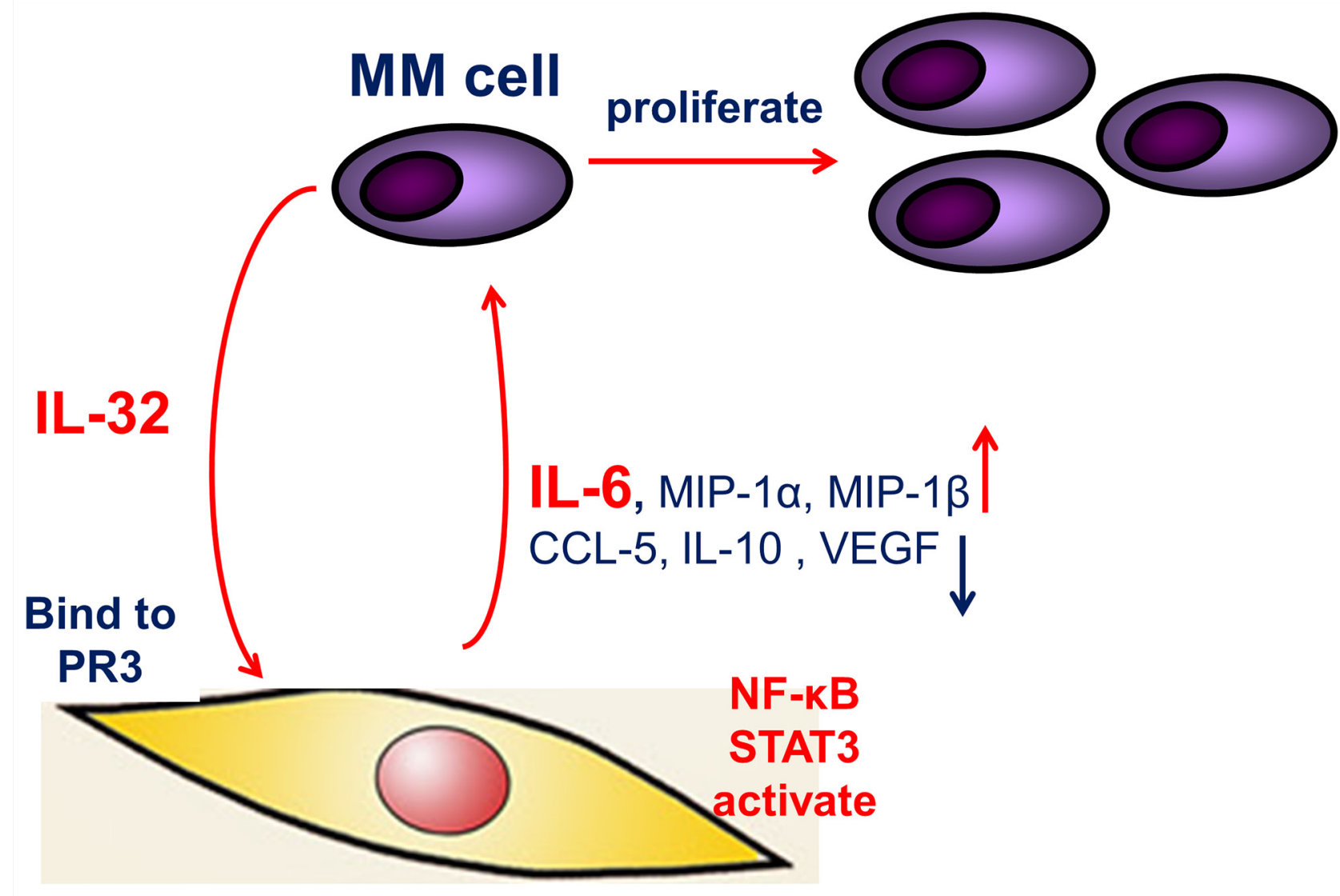

\section{BMSCs}

Figure 8: The proposed mechanism underlying the observed pro-inflammation effect of IL-32. IL-32 secreted from MM cells, increases IL-6 expression in BMSCs through activating NF- $\kappa$ B and STAT3 inflammation signaling pathways, thus feedback to support MM cells, resulting in the proliferation and growth of MM cells. 
capable of multiple biological functions. It is a major autoantigen in Wegener's granulomatosis, a systemic vasculitic disease [43-45]. As previous studies have reported, PR3 is an IL-32 binding protein that cleaves recombinant IL-32 into separate domains and make it more active than the intrinsic protein, especially IL-32 $\alpha$ and IL-32 $\beta[30,38$, 46]. Hence, it is considered a receptor of extracellular IL32. In this study, our data suggested that the expression of PR3 in BMSCs was significantly increased compared with MM cells, which might be one reason that IL-32 did not show strong autocrine stimulation in MM cells but affected BMSCs. Additionally, we verified that BMSCs with low expression of PR3 reduced the effects induced by IL-32. These data indicated that the binding of IL-32 and PR3 may be critical in the production of IL- 6 in the MM BM microenvironment.

Moreover, our group assayed additional cytokines induced by IL-32. In a previous study from our group, we found that MIP- $1 \alpha$ and MIP-1 $\beta$ were highly expressed in myeloma cells, and MIP-1 $\alpha$ was positively correlated with the infiltration of tumor associated macrophages [47]. IL-10 is a well-known anti-inflammatory factor involved in inflammation [48]. MIP-1 $\alpha$, MIP-1 $\beta$ and IL-10 are all primarily from $\mathrm{MM}$ cells or macrophages in the BM microenvironment [47-49]. Although IL-32 increased or decreased the production of these cytokines or chemokines in BMSCs, we doubt that these effects have a profound influence on MM cells, as the basement secretion in BMSCs is rather low. Interestingly, VEGF, a key cytokine mediates BM angiogenesis in MM [4], decreased significantly. Recently, Bak et al. reported that IL-32 $\theta$, a new isoform of IL-32, downregulates CCL5 expression through interaction with PKCE and STAT3 [50]. In MM, CCL5 is involved in osteolysis [51, 52]. Further studies regarding the relationships and mechanisms between VEGF, CCL5 and IL-32 $\alpha$ in MM are underway in our group.

To summarize, our study analyzed the expression of IL-32 and its binding receptor PR3 in MM BM, and demonstrated that in the MM BM microenvironment, IL32 induces production of IL- 6 in BMSCs by activating the $\mathrm{NF}-\kappa \mathrm{B}$ and STAT3 signaling pathways, thus promoting the proliferation of MM cells (Figure 8). In expectation, IL-32 may be a new biomarker in MM diagnoses and an optimal therapy target in MM treatment.

\section{MATERIALS AND METHODS}

\section{Human myeloma cell lines, primary myeloma cells, and human bone marrow stromal cells}

Human MM cell lines RPMI8226, OPM2, U266, MM.1S, H929, LP-1 and ANBL-6 were kindly provided by Dr Qing Yi (Department of Cancer Biology, Lerner Research Institute, Cleveland Clinic, OH, USA) and Dr Zhiqiang Liu (Department of Pathology and Pathophysiology, Tianjin Medical University, Tianjin,
China). MM cells were obtained from MM patients BM aspirates and purified by positive selection with CD138 microbeads (Miltenyi Biotech, CA, USA). A part of CD138 negative cells were collected for qRT-PCR and the rest were cultured for about 1 week. Then then suspended cells were discarded, and the adherent cells were identified by flow cytometry analysis as previously described [47, 53] and considered as BMSCs.

BM aspirates, BM biopsies and blood samples were obtained from newly diagnosed untreated MM patients and healthy donors. All human participants provided written informed consent, and the study protocol was approved by the Ethics Committee of the First Affiliated Hospital, Zhejiang University School of Medicine. The plasma of BM aspirates and serum were used for ELISA detection of cytokines. Cells from BM biopsies were used for immunofluorescence analysis.

\section{Cell culture}

RPMI8226, OPM2, H929, LP-1, ANBL-6, MM BMSCs and primary MM cells were cultured in RPMI 1640 medium (Thermo Scientific, HyClone) containing $10 \%$ fetal bovine serum (FBS) (Thermo Fisher Scientific, Gibco), and $1 \% \mathrm{~L}$-glutamine at $37^{\circ} \mathrm{C}$ and $5 \% \mathrm{CO}_{2}$.

Bone marrow stromal cells conditioned medium (BCCM) was prepared as follows: bone marrow stromal cells were cultured at a density of $2 \times 10^{5} / \mathrm{mL}$ in RPMI1640 containing $10 \% \mathrm{FBS}$ in the presence of $0-80 \mathrm{ng} /$ $\mathrm{mL}$ rIL-32 $\alpha$. Culture medium was collected after $24 \mathrm{~h}$ and stored at $4^{\circ} \mathrm{C}$ for up to $1 \mathrm{wk}$ before use. We diluted BCCM with fresh complete medium (50\% BCCM to 50\% complete medium) to apply for further studies.

When BMSCs reached 70\% confluence in 24-well plates, MM cell lines $\left(2 \times 10^{5}\right.$ cells per well $)$ were put in Transwell inserts (pore size: $0.4 \mu \mathrm{m}$, Corning) and cocultured with BMSCs for 24, 48 and $72 \mathrm{~h}$. Then, culture medium supernatant was prepared for ELISA, or $100 \mu \mathrm{L}$ MM cells suspension was aspirated for CCK8 analysis.

\section{Reagents and antibodies}

Recombinant human IL-32 $\alpha$ (rIL-32 $\alpha$ ), Recombinant human IL-6 (rIL-6) and neutralization antibodies to human IL-6 were purchased from R\&D systems (Minneapolis, MN, USA). Antibodies to human IL-32, PR3, and immunofluorescence antibody to IL-32 were purchased from Abcam (Cambridge, UK). Western blot antibodies to STAT3, pSTAT3 Ser-727, pSTAT3 Tyr-727, p38MAPK, pp38MAPK, p65 and pp65 were purchased from Cell Signaling Technology (Danvers, MA, USA). NF- $\kappa$ B inhibitor QNZ and STAT3 inhibitor BP-1102 were purchased from Selleckchem (Houston, TX, USA). Primary antibody against GAPDH was purchased from Sigma-Aldrich. Horseradish peroxidase (HRP)conjugated anti-rabbit and anti-mouse antibodies were 
purchased from Jackson Immuno research Laboratories (West Grove, PA, USA).

\section{Enzyme-linked immunosorbent assay (ELISA) and cytokine array}

A Human IL-32 Duoset ELISA kit was purchased from R\&D systems (Minneapolis, MN, USA). IL-6 ELISA and TNF- $\alpha$ ELISA kits were purchased from DAKEWE (Beijing, China). Cytokines were detected by following the manufacturer's instructions. Cytokine array technology and analysis was provided by RayBiotech (Guangzhou, China).

\section{Cell proliferation assays}

A CCK8 assay was used to detect MM cells and BMSCs proliferation. MM cells $\left(1-2 \times 10^{4}\right.$ cells per well) or BMSCs $\left(2-4 \times 10^{3}\right.$ cells per well $)$ were cultured in 96well plates for 24,48 and $72 \mathrm{~h}$, with or without stimulation of rIL-32 $\alpha$; preparation of MM cells co-cultured with BMSCs was mentioned above. Cells were treated with $10 \mu \mathrm{L}$ of CCK8 solution and incubated at $37^{\circ} \mathrm{C}$ for another 1-2h. A microplate reader (Bio-Rad, Model 680) was used to measure the absorbance at $450 \mathrm{~nm}$. Cell viability (\%) $=$ OD value of test sample/ OD value of control $\times 100 \%$.

\section{Immunofluorescence}

Cells from BM biopsies were seeded on cover glass and fixed in $4 \%$ paraformaldehyde for $30 \mathrm{~min}$ in $4{ }^{\circ} \mathrm{C}$. Then, $0.3 \%$ Triton X-100 was used to permeabilize cells for $10 \mathrm{~min}$. After three washes with PBS, the cells were immunostained with anti-IL-32 and anti-CD138 (Abcam, Cambridge, UK) at $4^{\circ} \mathrm{C}$ overnight. Subsequently, after washing, cells were incubated with goat anti-mouse IgG (Invitrogen, USA) in the dark. Then, cells were washed again and incubated in the dark with DAPI (Wako, Osaka, Japan) for $5 \mathrm{~min}$. Finally, photos were taken using fluorescence microscopy (Olympus, Tokyo, Japan).

\section{RT-PCR}

Total RNA was isolated using RNAiso ${ }^{\mathrm{TM}}$ Plus (TaKaRa, Shiga, Japan) according to the instructions. cDNA was generated using a PrimeScript ${ }^{\mathrm{TM}} \mathrm{T}$ Reagent Kit with DNA Eraser (TaKaRa, Shiga, Japan). RT-PCR was performed in a GeneAmp PCR System 9700 (Applied Biosystems, Thermo Fisher Scientific, MA, USA), and quantitative RTPCR was performed in a CFX96 Real-Time System (Bio-Rad, CA, USA), following the manufacturer's instructions. The primer sequences for IL-32(total) were (forward) 5'-AAGCTGAAGGCCCGAATG-3' and (reverse) 5'-CCTCGGCACCGTAATCCA-3'. The primer sequences for IL-32 $\alpha$ were (forward) 5'-GCTGGAGGACGACTTCAAAGA-3' and (reverse)
5'- GGGCTCCGTAGGACTTGTCA-3'. The primer sequences for IL-32 $\beta$ were (forward) 5'-CAGTGGAG CTGGGTCATCTCA-3' and (reverse) 5'- GGGCCT TCAGCTTCTTCATGTCATCA-3'. The primer sequences for IL-32 $\gamma$ were (forward) 5'-AGGCCCGAATGGTAAT GCT-3' and (reverse) 5' - CCACAGTGTCCTCAGTGT CACA-3'. The primer sequences for PR3 were (forward) 5'-CACTGCCTGCGGGACATA-3' and (reverse) 5'-ACACCTGAGCCACCGAGAA-3'.

\section{Western blot analysis}

Cells were collected and extracted with RIPA buffer. Supernatants were collected for Western blot. Briefly, 20$40 \mu \mathrm{g}$ of proteins were separated by $8 \%-12 \%$ sodium dodecyl sulfate-polyacrylamide gel electrophoresis and transferred to polyvinylidene difluoride membranes (Merck Millipore, Germany). The membranes were blocked with $5 \%$ bovine serum albumin for $1-2 \mathrm{~h}$ and then incubated with primary antibodies overnight at $4^{\circ} \mathrm{C}$. The membranes were washed the next day with Tris-buffered saline with Tween 20 (TBS-T) and then incubated with HRP-conjugated anti-rabbit or anti-mouse antibodies for $2 \mathrm{~h}$ at room temperature. The membranes were washed with TBS-T again, and protein bands were detected using a ChemiDoc ${ }^{\mathrm{TM}}$ MP Imaging System (Bio-Rad) with an enhanced chemiluminescence detection kit for HRP (Biological Industries, Israel, Beit Haemek Ltd.).

\section{Transfection of BMSCs and MM cells}

BMSCs were cultured in 12 -well plates $\left(2 \times 10^{5}\right.$ cells per well) the day before transfection. When cells reached $70 \%$ confluence, they were transfected with PR3 siRNA (Vigene Biosciences, Rockville, USA) (forward, 5'-CGGAGAACAAACUGAACGA-3', and reverse, 5'-UCGUUCAGUUUGUUCUCCG-3') using lipofectamine ${ }^{\mathrm{TM}} 2000$ (Invitrogen, USA). Control group of MM cells were transfected with siRNA (Vigene Biosciences, Rockville, USA) (forward, 5'-UUCUCCGAACGUGUCACGU-3', and reverse, 5'-ACGUGACACGUUCGGAGAA-3'). After $6 \mathrm{~h}$, the transfection medium (Opti-MEM) was removed and replaced with fresh complete medium. After 48-72 h, BMSCs were collected and Western blot was used to verify the efficiency of the transfection.

MM cells were seeded in 24 -well plates $\left(5 \times 10^{4}\right.$ cells per well) and transfected with IL-32 shRNA (Vigene Biosciences, Rockville, USA) (GATCCGTGACAAGGT CATGAGATGGTTCTTCAAGAGAGAACCATCTCAT GACCTTGTCACTTTTTTA) using pLent-U6-GFP-Puro vectors. Control group of MM cells were transfected with empty vectors. After 5-7 days, MM cells were collected and cultured in medium with puromycin $(1 \mu \mathrm{g} / \mathrm{mL})$ to select for well-transfected MM cells. After another 1-2 weeks, Western blot was used to verify the efficiency of transfection. 


\section{Statistical analysis}

Results are presented as the mean $\pm \mathrm{SD}$ of at least three independent experiments. Two-tailed Student's t-test was used to analyze significant differences between two groups and one-way ANOVA was used to estimate between three or more groups. $p$ values $<0.05$ were considered statistically significant. All analyses were performed using GraphPad Prism 5.0 (GraphPad Software, CA, USA).

\section{Author contributions}

Z.C., L.Y. and F.Z. initiated the work and designed the experiments; X.L. and H.Y. performed the majority of the experiments; X.L. analyzed data and wrote the manuscript; X.G., J.C., Q.C., X.H., Y.L. and E.Z. performed the experiments; W.W., Y.Y., D.H. and J.H. provided samples and critical suggestions.

\section{CONFLICTS OF INTEREST}

The authors declare no competing financial interest.

\section{FUNDING}

This work was supported by grants from the National Natural Science Foundation of China (91429302, 81471532 and 31371380).

\section{REFERENCES}

1. Siegel RL, Miller KD, Jemal A. Cancer statistics, 2016. CA Cancer J Clin. 2016; 66: 7-30.

2. Malard F, Harousseau JL, Mohty M. Multiple myeloma treatment at relapse after autologous stem cell transplantation: a practical analysis. Cancer Treat Rev. 2017; 52: 41-7.

3. Mahindra A, Laubach J, Raje N, Munshi N, Richardson PG, Anderson K. Latest advances and current challenges in the treatment of multiple myeloma. Nat Rev Clin Oncol. 2012; 9: 135-43.

4. Jurczyszyn A, Gdula-Argasińska J, Kosmaczewska A, Skotnicki AB. [The role of the bone marrow microenvironment in the pathogenesis of multiple myeloma]. [Article in Polish]. Postepy Hig Med Dosw (Online). 2015; 69: 521-33.

5. Kawano Y, Moschetta M, Manier S, Glavey S, Görgün GT, Roccaro AM, Anderson KC, Ghobrial IM. Targeting the bone marrow microenvironment in multiple myeloma. Immunol Rev. 2015; 263: 160-72.

6. Shay G, Hazlehurst L, Lynch CC. Dissecting the multiple myeloma-bone microenvironment reveals new therapeutic opportunities. J Mol Med (Berl). 2016; 94: 21-35.
7. Brown LM, Gridley G, Check D, Landgren O. Risk of multiple myeloma and monoclonal gammopathy of undetermined significance among white and black male United States veterans with prior autoimmune, infectious, inflammatory, and allergic disorders. Blood. 2008; 111: 3388-94.

8. Mansell A, Jenkins BJ. Dangerous liaisons between interleukin-6 cytokine and toll-like receptor families: a potent combination in inflammation and cancer. Cytokine Growth Factor Rev. 2013; 24: 249-56.

9. Fan Y, Mao R, Yang J. NF-kappaB and STAT3 signaling pathways collaboratively link inflammation to cancer. Protein Cell. 2013; 4: 176-85.

10. Wu D, Guo X, Su J, Chen R, Berenzon D, Guthold M, Bonin K, Zhao W, Zhou X. CD138-negative myeloma cells regulate mechanical properties of bone marrow stromal cells through SDF-1/CXCR4/AKT signaling pathway. Biochim Biophys Acta. 2015; 1853: 338-47.

11. Maruyama D, Watanabe T, Heike Y, Nagase K, Takahashi N, Yamasaki S, Waki F, Yokoyama H, Kim SW, Kobayashi Y, Aizawa S, Tobinai K. Stromal cells in bone marrow play important roles in pro-inflammatory cytokine secretion causing fever following bortezomib administration in patients with multiple myeloma. Int J Hematol. 2008; 88: 396-402.

12. Jego G, Bataille R, Geffroy-Luseau A, Descamps G, PellatDeceunynck C. Pathogen-associated molecular patterns are growth and survival factors for human myeloma cells through Toll-like receptors. Leukemia. 2006; 20: 1130-7.

13. Dahl CA, Schall RP, He HL, Cairns JS. Identification of a novel gene expressed in activated natural killer cells and $\mathrm{T}$ cells. J Immunol. 1992; 148: 597-603.

14. Heinhuis B, Koenders MI, van de Loo FA, Netea MG, van den Berg WB, Joosten LA. Inflammation-dependent secretion and splicing of IL-32 \{gamma\} in rheumatoid arthritis. Proc Natl Acad Sci U S A. 2011; 108: 4962-7.

15. Heinhuis B, Koenders MI, van Riel PL, van de Loo FA, Dinarello CA, Netea MG, van den Berg WB, Joosten LA. Tumour necrosis factor alpha-driven IL-32 expression in rheumatoid arthritis synovial tissue amplifies an inflammatory cascade. Ann Rheum Dis. 2011; 70: 660-7.

16. Khawar MB, Abbasi MH, Sheikh N. IL-32: a novel pluripotent inflammatory interleukin, towards gastric inflammation, gastric cancer, and chronic rhino sinusitis. Mediators Inflamm. 2016; 2016: 8413768.

17. Joosten LA, Heinhuis B, Netea MG, Dinarello CA. Novel insights into the biology of interleukin-32. Cell Mol Life Sci. 2013; 70: 3883-92.

18. Heinhuis B, Netea MG, van den Berg WB, Dinarello CA, Joosten LA. Interleukin-32: a predominantly intracellular proinflammatory mediator that controls cell activation and cell death. Cytokine. 2012; 60: 321-7.

19. Tsai CY, Wang CS, Tsai MM, Chi HC, Cheng WL, Tseng YH, Chen CY, Lin CD, Wu JI, Wang LH, Lin KH. 
Interleukin-32 increases human gastric cancer cell invasion associated with tumor progression and metastasis. Clin Cancer Res. 2014; 20: 2276-88.

20. Nishida A, Andoh A, Inatomi O, Fujiyama Y. Interleukin-32 expression in the pancreas. J Biol Chem. 2009; 284: 17868-76.

21. Lee HJ, Liang ZL, Huang SM, Lim JS, Yoon DY, Lee HJ, Kim JM. Overexpression of IL-32 is a novel prognostic factor in patients with localized clear cell renal cell carcinoma. Oncol Lett. 2012; 3: 490-6.

22. Goda C, Kanaji T, Kanaji S, Tanaka G, Arima K, Ohno S, Izuhara K. Involvement of IL-32 in activation-induced cell death in T cells. Int Immunol. 2006; 18: 233-40.

23. Marcondes AM, Mhyre AJ, Stirewalt DL, Kim SH, Dinarello CA, Deeg HJ. Dysregulation of IL-32 in myelodysplastic syndrome and chronic myelomonocytic leukemia modulates apoptosis and impairs NK function. Proc Natl Acad Sci U S A. 2008; 105: 2865-70.

24. Kim SH, Han SY, Azam T, Yoon DY, Dinarello CA. Interleukin-32: a cytokine and inducer of TNFalpha. Immunity. 2005; 22: 131-42.

25. Netea MG, Azam T, Ferwerda G, Girardin SE, Walsh M, Park JS, Abraham E, Kim JM, Yoon DY, Dinarello CA, Kim SH. IL-32 synergizes with nucleotide oligomerization domain (NOD) 1 and NOD2 ligands for IL-1beta and IL-6 production through a caspase 1-dependent mechanism. Proc Natl Acad Sci U S A. 2005; 102: 16309-14.

26. Netea MG, Lewis EC, Azam T, Joosten LA, Jaekal J, Bae SY, Dinarello CA, Kim SH. Interleukin-32 induces the differentiation of monocytes into macrophage-like cells. Proc Natl Acad Sci U S A. 2008; 105: 3515-20.

27. Park MH, Song MJ, Cho MC, Moon DC, Yoon DY, Han $\mathrm{SB}$, Hong JT. Interleukin-32 enhances cytotoxic effect of natural killer cells to cancer cells via activation of death receptor 3. Immunology. 2012; 135: 63-72.

28. Bai X, Kim SH, Azam T, McGibney MT, Huang H, Dinarello CA, Chan ED. IL-32 is a host protective cytokine against Mycobacterium tuberculosis in differentiated THP-1 human macrophages. J Immunol. 2010; 184: 3830-40.

29. Hasegawa H, Thomas HJ, Schooley K, Born TL. Native IL-32 is released from intestinal epithelial cells via a nonclassical secretory pathway as a membrane-associated protein. Cytokine. 2011; 53: 74-83.

30. Novick D, Rubinstein M, Azam T, Rabinkov A, Dinarello CA, Kim SH. Proteinase 3 is an IL-32 binding protein. Proc Natl Acad Sci U S A. 2006; 103: 3316-21.

31. Seo EH, Kang J, Kim KH, Cho MC, Lee S, Kim HJ, Kim JH, Kim EJ, Park DK, Kim SH, Choi YK, Kim JM, Hong JT, Yoon DY. Detection of expressed IL-32 in human stomach cancer using ELISA and immunostaining. J Microbiol Biotechnol. 2008; 18: 1606-12.

32. Na SJ, So SH, Lee KO, Choi YC. Elevated serum level of interleukin-32alpha in the patients with myasthenia gravis. J Neurol. 2011; 258: 1865-70.
33. Heinhuis B, Koenders MI, van den Berg WB, Netea MG, Dinarello CA, Joosten LA. Interleukin 32 (IL-32) contains a typical alpha-helix bundle structure that resembles focal adhesion targeting region of focal adhesion kinase-1. J Biol Chem. 2012; 287: 5733-43.

34. Cheon S, Lee JH, Park S, Bang SI, Lee WJ, Yoon DY, Yoon SS, Kim T, Min H, Cho BJ, Lee HJ, Lee KW, Jeong SH, et al. Overexpression of IL-32alpha increases natural killer cell-mediated killing through up-regulation of Fas and UL16binding protein 2 (ULBP2) expression in human chronic myeloid leukemia cells. J Biol Chem. 2011; 286: 12049-55.

35. Kang JW, Park YS, Lee DH, Kim JH, Kim MS, Bak Y, Hong J, Yoon DY. Intracellular interaction of interleukin (IL)-32alpha with protein kinase Cepsilon (PKCepsilon) and STAT3 protein augments IL-6 production in THP-1 promonocytic cells. J Biol Chem. 2012; 287: 35556-64.

36. Oh JH, Cho MC, Kim JH, Lee SY, Kim HJ, Park ES, Ban JO, Kang JW, Lee DH, Shim JH, Han SB, Moon DC, Park $\mathrm{YH}$, et al. IL-32gamma inhibits cancer cell growth through inactivation of NF-kappaB and STAT3 signals. Oncogene. 2011; 30: 3345-59.

37. Yun HM, Oh JH, Shim JH, Ban JO, Park KR, Kim JH, Lee DH, Kang JW, Park YH, Yu D, Kim Y, Han SB, Yoon DY, Hong JT. Antitumor activity of IL-32beta through the activation of lymphocytes, and the inactivation of NF-kappaB and STAT3 signals. Cell Death Dis. 2013; 4: e640.

38. Kim S, Lee S, Her E, Bae S, Choi J, Hong J, Jaekal J, Yoon D, Azam T, Dinarello CA, Kim S. Proteinase 3-processed form of the recombinant IL-32 separate domain. BMB Rep. 2008; 41: 814-9.

39. Burger R. Impact of interleukin-6 in hematological malignancies. Transfus Med Hemother. 2013; 40: 336-43.

40. Sansone P, Storci G, Tavolari S, Guarnieri T, Giovannini C, Taffurelli M, Ceccarelli C, Santini D, Paterini P, Marcu $\mathrm{KB}$, Chieco $\mathrm{P}$, Bonafè M. IL-6 triggers malignant features in mammospheres from human ductal breast carcinoma and normal mammary gland. J Clin Invest. 2007; 117: 3988-4002.

41. Grivennikov S, Karin E, Terzic J, Mucida D, Yu GY, Vallabhapurapu S, Scheller J, Rose-John S, Cheroutre H, Eckmann L, Karin M. IL-6 and Stat3 are required for survival of intestinal epithelial cells and development of colitis-associated cancer. Cancer Cell. 2009; 15: 103-13.

42. Gao SP, Mark KG, Leslie K, Pao W, Motoi N, Gerald WL, Travis WD, Bornmann W, Veach D, Clarkson B, Bromberg JF. Mutations in the EGFR kinase domain mediate STAT3 activation via IL-6 production in human lung adenocarcinomas. J Clin Invest. 2007; 117: 3846-56.

43. Frosch M, Foell D. Wegener granulomatosis in childhood and adolescence. Eur J Pediatr. 2004; 163: 425-34.

44. Lamprecht P, Gross WL. Wegener's granulomatosis. Herz. 2004; 29: 47-56. 
45. Csernok E, Holle JU, Gross WL. Proteinase 3, proteaseactivated receptor-2 and interleukin-32: linking innate and autoimmunity in Wegener's granulomatosis. Clin Exp Rheumatol. 2008; 26: S112-7.

46. Nakayama M, Niki Y, Kawasaki T, Takeda Y, Ikegami $\mathrm{H}$, Toyama Y, Miyamoto T. IL-32-PAR2 axis is an innate immunity sensor providing alternative signaling for LPSTRIF axis. Sci Rep. 2013; 3: 2960.

47. Li Y, Zheng Y, Li T, Wang Q, Qian J, Lu Y, Zhang M, Bi E, Yang M, Reu F, Yi Q, Cai Z. Chemokines CCL2, 3, 14 stimulate macrophage bone marrow homing, proliferation, and polarization in multiple myeloma. Oncotarget. 2015; 6: 24218-29. https://doi.org/10.18632/ oncotarget. 4523 .

48. Alexandrakis MG, Goulidaki N, Pappa CA, Boula A, Psarakis F, Neonakis I, Tsirakis G. Interleukin-10 induces both plasma cell proliferation and angiogenesis in multiple myeloma. Pathol Oncol Res. 2015; 21: 929-34.
49. Otsuki T, Yata K, Sakaguchi H, Uno M, Fujii T, Wada H, Sugihara T, Ueki A. IL-10 in myeloma cells. Leuk Lymphoma. 2002; 43: 969-74.

50. Bak Y, Kang JW, Kim MS, Park YS, Kwon T, Kim S, Hong J, Yoon DY. IL-32 $\theta$ downregulates CCL5 expression through its interaction with $\mathrm{PKC} \delta$ and STAT3. Cell Signal. 2014; 26: 3007-15.

51. Barille-Nion S, Bataille R. New insights in myelomainduced osteolysis. Leuk Lymphoma. 2003; 44: 1463-7.

52. Moller C, Strömberg T, Juremalm M, Nilsson K, Nilsson G. Expression and function of chemokine receptors in human multiple myeloma. Leukemia. 2003; 17: 203-10.

53. Zi FM, He JS, Li Y, Wu C, Wu WJ, Yang Y, Wang LJ, He DH, Yang L, Zhao Y, Zheng GF, Han XY, Huang H, et al. Fibroblast activation protein protects bortezomib-induced apoptosis in multiple myeloma cells through beta-catenin signaling pathway. Cancer Biol Ther. 2014; 15: 1413-22. 